\title{
Hubungan status gizi dengan tekanan darah pada siswa SD Katolik RK IV Santo Yohanes Manado
}

\author{
${ }^{1}$ Keren E. K. Mantik \\ ${ }^{2}$ Adrian Umboh \\ ${ }^{2}$ Rocky Wilar
}

\author{
${ }^{1}$ Kandidat Skripsi Fakultas Kedokteran Universitas Sam Ratulangi Manado \\ ${ }^{2}$ Bagian Ilmu Kesehatan Anak Fakultas Kedokteran Universitas Sam Ratulangi Manado \\ Email: krnmantik@gmail.com
}

\begin{abstract}
Nutritional status problems such as undernutrition and overnutrition are still widespread in Indonesia. Nutritional status, notably overnutrition, may result in increased blood pressure through the mechanisms of increased leptin, insulin resistance, increased free fatty acids, and activation of the renin-angiotensin-aldosterone system. This study was aimed to determine the relationship between nutritional status and blood pressure (systolic and diastolic) in Santo Yohanes IV Catholic Elementary School students. This was an observational analytical study with a cross-sectional design. Sampling was conducted among students at Santo Yohanes IV Catholic Elementary School from August 2016 until November 2016 using consecutive sampling method. Total samples were 152 students.. The chi-square test showed that there was a relationship between nutritional status and systolic as well as diastolic blood pressure $(\mathrm{p}=0.003)$. The Spearman correlation test concerning nutritional status with systolic and diastolic blood pressure showed the $\mathrm{r}$ values of 0.321 and 0.319 , respectively. Conclusion: There was a significant relationship between nutritional status and blood pressure (systolic and diastolic) in school-aged children, however, overweight and obese children had higher risks of elevated blood pressure (systolic and diastolic).
\end{abstract}

Keywords: nutrirional status, blood pressure, school-aged children

\begin{abstract}
Abstrak: Masalah status gizi seperti gizi kurang dan gizi lebih masih tersebar luas di Indonesia. Status gizi terutama gizi lebih dapat berdampak pada meningkatnya tekanan darah melalui mekanisme peningkatan kadar leptin, resistensi insulin, peningkatan kadar asam lemak bebas, dan aktivasi sistem renin-angiotensin-aldosteron. Penelitian ini bertujuan untuk mengetahui hubungan status gizi dengan tekanan darah (sistolik dan diastolik) pada siswa SD Katolik RK IV Santo Yohanes Manado. Jenis penelitian ialah survei analitik observasional dengan desain potong lintang. Pengambilan sampel dilakukan di SD Katolik RK IV Santo Yohanes Manado dari bulan Agustus 2016 sampai November 2016 dengan metode consecutive sampling berjumlah 152 siswa. Hasil uji chi-square terhadap status gizi dengan tekanan darah sistolik dan diastolik menunjukkan terdapat hubungan antara status gizi dengan tekanan darah baik sistolik maupun diastolik $(\mathrm{p}=0,003)$. Dari uji korelasi Spearman terhadap status gizi dengan tekanan darah sistolik dan diastolik diperoleh nilai $r$ masing-masing yaitu 0,321 dan 0,319. Simpulan: Terdapat hubungan bermakna antara status gizi dengan tekanan darah (sistolik dan diastolik) pada anak usia sekolah. Anak dengan overweight dan obese mempunyai risiko lebih tinggi terhadap peningkatan tekanan darah (sistolik dan diastolik).
\end{abstract}

Kata kunci: status gizi, tekanan darah, anak usia sekolah 
Status gizi didefinisikan sebagai keadaan tubuh yang merupakan akibat konsumsi makanan dan penggunaan zat-zat gizi. Status gizi dibedakan antara status gizi buruk, gizi kurang (undernutrition), gizi baik, dan gizi lebih (overnutrition). ${ }^{1}$ Beberapa bentuk dari gizi kurang yaitu berat badan kurang (underweight), pendek (stunting), kurus (wasting), dan defisiensi mikronutrien sedangkan gizi lebih dapat berupa berat badan lebih (overweight) atau obesitas. $^{2}$

Masalah gizi telah menjadi prioritas utama dalam program bidang kesehatan di seluruh dunia. Gizi kurang masih tersebar luas di negara-negara berkembang, termasuk di Indonesia. Pada sisi lain, masalah gizi lebih yang merupakan masalah gizi di negara maju mulai terlihat di negara-negara berkembang seperti di Indonesia. ${ }^{3,4}$ Menurut Riset Kesehatan Dasar (Riskesdas) tahun 2013, prevalensi underweight pada anak berusia 5-12 tahun secara nasional ialah $11,2 \%$ sedangkan prevalensi overweight pada anak berusia 512 tahun ialah $18,8 \% .^{5}$

Status gizi berhubungan erat dengan tekanan darah. Gizi kurang yang terjadi pada masa maternal seperti bayi berat lahir rendah (BBLR) dan pertumbuhan janin terhambat berpengaruh terhadap tekanan darah saat dewasa. ${ }^{6}$ Pada individu dengan obesitas, terjadi peningkatan asam lemak bebas dan insulin yang memicu aktivasi sistem saraf simpatis. Apabila hal ini berlangsung lama, maka akan terjadi retensi natrium dan air yang menyebabkan terjadinya hipertensi. Pada obesitas juga terjadi peningkatan kadar leptin dan aktivasi sistem renin-angiotensinaldosteron (RAAS) yang dapat menyebabkan retensi natrium dan air serta memicu aktifasi sistem saraf simpatis. Peningkatan produksi endotelin-1 juga dapat menyebabkan vasokonstriksi yang bermuara pada terjadinya hipertensi.

Dalam studi yang dilakukan di Brazil pada anak-anak berusia 2 sampai 7 tahun, terdapat peningkatan tekanan darah sistolik dan tekanan darah diastolik pada anak yang mengalami stunting dibandingkan dengan anak yang normal. ${ }^{8}$ Pada studi yang dilakukan di Thailand tahun 2014, didapatkan bahwa obesitas dan tekanan darah pada anak usia sekolah (8-12 tahun) berhubungan erat. ${ }^{9}$ Hal yang sama juga ditemukan pada penelitian di United Arab Emirates dimana tekanan darah tinggi sangat berhubungan dengan angka kejadian overweight pada anak dan remaja usia sekolah. ${ }^{10}$

Penelitian ini bertujuan untuk mengetahui hubungan status gizi dengan tekanan darah (sistolik dan diastolik) pada siswa SD Katolik RK IV Santo Yohanes Manado.

\section{METODE PENELITIAN}

Jenis penelitian ini ialah survei analitik observasional dengan desain potong lintang. Pengambilan sampel dilakukan di SD Katolik RK IV Santo Yohanes Manado dari bulan Agustus 2016 -November 2016 dengan metode consecutive sampling. Populasi penelitian ialah siswa-siswi SD Katolik RK IV Santo Yohanes Manado sedangkan sampel penelitian ialah siswa kelas 1 - kelas 6 SD Katolik RK IV Santo Yohanes Manado.

Variabel bebas penelitian ialah status gizi dan variabel tergantung ialah tekanan darah. Data diperoleh melalui pengukuran tinggi badan, berat badan, dan tekanan darah. Analisis data dilakukan menggunakan program SPSS dengan uji chi-square dan uji korelasi Spearman.

\section{HASIL PENELITIAN}

Dari 153 siswa yang hadir saat pengambilan data, 1 siswa tidak memenuhi kriteria inklusi sehingga total sampel yang diperoleh berjumlah 152 siswa. Tabel 1 memperlihatkan bahwa dari 9 siswa dengan status gizi underweight, terdapat 5 siswa $(55,6 \%)$ laki-laki dan 4 siswa $(44,4 \%)$ perempuan. Dari 93 siswa dengan status gizi normal, terdapat 46 siswa $(49,5 \%)$ laki-laki dan 47 siswa $(50,5 \%)$ perempuan. Dari 23 siswa dengan status gizi overweight, terdapat 11 siswa $(47,8 \%)$ lakilaki dan 12 siswa $(52,2 \%)$ perempuan. Dari 27 siswa dengan status gizi obese, terdapat 
16 siswa $(59,3 \%)$ laki-laki dan 11 siswa $(40,7 \%)$ perempuan.

Pada Tabel 2 dapat dilihat bahwa dari 129 siswa yang tergolong normal, terdapat 65 siswa $(50,4 \%)$ laki-laki dan 64 siswa $(49,6 \%)$ perempuan. Dari 11 siswa yang tergolong pre-hipertensi sistolik, terdapat 7 siswa $(63,6 \%)$ laki-laki dan 4 siswa $(36,4 \%)$ perempuan sedangkan dari 12 siswa yang tergolong hipertensi sistolik, terdapat 6 siswa $(50,0 \%)$ laki-laki dan 6 siswa $(50,0 \%)$ perempuan.

Pada Tabel 3 dapat dilihat bahwa dari 128 siswa yang memiliki tekanan darah diastolik normal, terdapat 67 siswa $(52,3 \%)$ laki-laki dan 61 siswa $(47,7 \%)$ perempuan. Dari 13 siswa yang tergolong pre-hipertensi diastolik, terdapat 5 siswa $(38,5 \%)$ laki-laki dan 8 siswa $(61,5 \%)$ perempuan sedangkan dari 11 siswa yang tergolong hipertensi diastolik, terdapat 6 siswa $(54,5 \%)$ laki-laki dan 5 siswa $(45,5 \%)$ perempuan.

Tabel 1. Distribusi status gizi berdasarkan jenis kelamin

\begin{tabular}{lccc}
\hline \multicolumn{1}{c}{$\begin{array}{c}\text { Status } \\
\text { gizi }\end{array}$} & \multicolumn{2}{c}{ Jenis kelamin } & \multirow{2}{*}{$\begin{array}{c}\text { Total } \\
\text { n }(\%)\end{array}$} \\
\cline { 2 - 3 } & $\begin{array}{c}\text { Laki-laki } \\
\mathrm{n}(\%)\end{array}$ & $\begin{array}{c}\text { Perempuan } \\
\mathrm{n}(\%)\end{array}$ & \\
\hline Under-weight & $5(55,6)$ & $4(44,4)$ & $9(100)$ \\
Normal & $46(49,5)$ & $47(50,5)$ & $93(100)$ \\
Over-weight & $11(47,8)$ & $12(52,2)$ & $23(100)$ \\
Obese & $16(59,3)$ & $11(40,7)$ & $27(100)$ \\
Total & $78(51,3)$ & $74(48,7)$ & $152(100)$ \\
\hline
\end{tabular}

Tabel 2. Distribusi tekanan darah sistolik berdasarkan jenis kelamin

\begin{tabular}{lccc}
\hline \multirow{2}{*}{$\begin{array}{l}\text { Tekanan } \\
\text { darah sistolik }\end{array}$} & \multicolumn{2}{c}{ Jenis kelamin } & \multirow{2}{*}{$\begin{array}{c}\text { Total } \\
\text { n }(\%)\end{array}$} \\
\cline { 2 - 3 } & $\begin{array}{c}\text { Laki-laki } \\
\mathrm{n}(\%)\end{array}$ & $\begin{array}{c}\text { Perempuan } \\
\mathrm{n}(\%)\end{array}$ & \\
\hline Normal & $65(50,4)$ & $64(49,6)$ & $129(100)$ \\
Pre-Hipertensi & $7(63,6)$ & $4(36,4)$ & $11(100)$ \\
Hipertensi & $6(50,0)$ & $6(50,0)$ & $12(100)$ \\
Total & $78(51,3)$ & $74(48,7)$ & $152(100)$ \\
\hline
\end{tabular}

Tabel 3. Distribusi tekanan darah diastolik berdasarkan jenis kelamin

\begin{tabular}{lccc}
\hline \multirow{2}{*}{$\begin{array}{l}\text { Tekanan } \\
\text { diastolik }\end{array}$} & \multicolumn{2}{c}{ Jenis kelamin } & Total \\
\cline { 2 - 3 } & $\begin{array}{c}\text { Laki-laki } \\
\mathrm{n}(\%)\end{array}$ & $\begin{array}{c}\text { Perempuan } \\
\mathrm{n}(\%)\end{array}$ & \\
\hline Normal & $67(52,3)$ & $61(47,7)$ & $128(100)$ \\
Pre-Hipertensi & $5(38,5)$ & $8(61,5)$ & $13(100)$ \\
Hipertensi & $6(54,5)$ & $5(45,5)$ & $11(100)$ \\
Total & $78(51,3)$ & $74(48,7)$ & $152(100)$ \\
\hline
\end{tabular}

Berdasarkan data pada Tabel 4, dapat dilihat bahwa dari 152 siswa yang dijadikan sampel, terdapat 119 siswa yang memiliki tekanan darah normal, 5 siswa mengalami pre-hipertensi sistolik, 7 siswa mengalami pre-hipertensi diastolik, 3 siswa mengalami pre-hipertensi sistolik dan diastolik, 4 siswa mengalami hipertensi sistolik, 3 siswa mengalami hipertensi diastolik, 3 siswa mengalami hipertensi sistolik dan pre-hipertensi diastolik, 3 siswa mengalami pre-hipertensi sistolik dan hipertensi diastolik, dan 5 siswa mengalami hipertensi sistolik dan diastolik. 
Tabel 4. Jumlah siswa berdasarkan kategori tekanan darah (sistolik dan diastolik)

\begin{tabular}{|c|c|c|}
\hline $\begin{array}{l}\text { Kategori } \\
\text { tekanan darah }\end{array}$ & $\mathbf{n}$ & $\%$ \\
\hline Normal & 119 & 78.3 \\
\hline Pre-hipertensi sistolik & 5 & 3.3 \\
\hline Pre-hipertensi diastolik & 7 & 4.6 \\
\hline $\begin{array}{l}\text { Pre-hipertensi sistolik } \\
\text { dan diastolik }\end{array}$ & 3 & 2 \\
\hline Hipertensi sistolik & 4 & 2.6 \\
\hline Hipertensi diastolik & 3 & 2 \\
\hline $\begin{array}{l}\text { Hipertensi sistolik dan } \\
\text { pre-hipertensi diastolik }\end{array}$ & 3 & 2 \\
\hline $\begin{array}{l}\text { Pre-hipertensi sistolik } \\
\text { dan hipertensi diastolik }\end{array}$ & 3 & 2 \\
\hline $\begin{array}{l}\text { Hipertensi sistolik dan } \\
\text { diastolik }\end{array}$ & 5 & 3.3 \\
\hline Total & 152 & 100 \\
\hline
\end{tabular}

Pada Tabel 5 dapat dilihat bahwa dari 9 siswa yang berstatus gizi underweight, tidak ditemukan pre-hipertensi maupun hipertensi. Dari 93 siswa yang berstatus gizi normal, terdapat 85 siswa $(91,4 \%)$ dengan tekanan darah sistolik yang tergolong normal, 4 siswa $(4,3 \%)$ yang tergolong pre-hipertensi, dan 4 siswa $(4,3 \%)$ yang tergolong hipertensi. Dari 23 siswa yang berstatus gizi overweight, diperoleh 19 siswa $(82,6 \%)$ dengan tekanan darah sistolik yang tergolong normal, 1 siswa $(4,3 \%)$ yang tergolong pre-hipertensi, dan 3 siswa $(13,0 \%)$ yang tergolong hipertensi. Pada 27 siswa berstatus gizi obese, terdapat 16 siswa $(59,3 \%)$ dengan tekanan darah sistolik yang tergolong normal, 6 siswa $(22,2 \%)$ yang tergolong pre-hipertensi, dan 5 siswa $(18,5 \%)$ yang tergolong hipertensi.

Berdasarkan hasil uji chi-square (Tabel 5), diperoleh nilai $\mathrm{p}=0,003$ ( $\mathrm{p}<$ 0,05 ) yang menunjukkan bahwa secara statistik terdapat hubungan bermakna antara status gizi dengan tekanan darah sistolik.

Berdasarkan hasil uji korelasi Spearman terhadap hubungan antara status gizi dan tekanan darah sistolik, diperoleh koefisien korelasi $\mathrm{r}=0,321$ dengan nilai $\mathrm{p}$ $=0,000$ (Tabel 6). Hasil ini menunjukkan secara statistik adanya hubungan bermakna antara status gizi dengan tekanan darah sistolik yaitu semakin besar status gizi atau indeks massa tubuh maka tekanan darah sistolik akan makin meningkat.

Tabel 5. Hubungan status gizi dengan tekanan darah sistolik

\begin{tabular}{lccccc}
\hline Status gizi & \multicolumn{3}{c}{ Tekanan darah sistolik } & Total & p \\
\cline { 2 - 4 } & $\begin{array}{c}\text { Normal } \\
\mathrm{n}(\%)\end{array}$ & $\begin{array}{c}\text { Pre-hipertensi } \\
\mathrm{n}(\%)\end{array}$ & $\begin{array}{c}\text { Hipertensi } \\
\mathrm{n}(\%)\end{array}$ & & \\
\hline Underweight & $9(100)$ & $0(0)$ & $0(0)$ & $9(100)$ & \\
Normal & $85(91,4)$ & $4(4,3)$ & $4(4,3)$ & $93(100)$ & 0,003 \\
Overweight & $19(82,6)$ & $1(4,3)$ & $3(13,0)$ & $23(100)$ & \\
Obese & $16(59,3)$ & $6(22,2)$ & $5(18,5)$ & $27(100)$ & \\
Total & $129(84,9)$ & $11(7,2)$ & $12(7,9)$ & $152(100)$ & \\
\hline
\end{tabular}

Tabel 6. Uji korelasi hubungan status gizi dan tekanan darah sistolik

\begin{tabular}{lcc}
\hline & $\begin{array}{c}\text { Koefisien } \\
\text { korelasi } \\
(\mathbf{r})\end{array}$ & $\begin{array}{c}\text { Kemaknaan } \\
(\mathbf{p})\end{array}$ \\
\hline $\begin{array}{l}\text { Hubungan } \\
\text { status gizi } \\
\text { dengan tekanan } \\
\text { darah sistolik }\end{array}$ & 0,321 & 0,000 \\
\hline
\end{tabular}

Pada Tabel 7 dapat dilihat bahwa dari 9 siswa yang berstatus gizi underweight, tidak ditemukan siswa yang tergolong prehipertensi maupun hipertensi. Dari 93 siswa yang berstatus gizi normal, terdapat 85 siswa $(91,4 \%)$ dengan tekanan darah diastolik yang tergolong normal, 6 siswa $(6,5 \%)$ yang tergolong pre-hipertensi, dan 2 siswa $(2,2 \%)$ yang tergolong hipertensi. Dari 23 siswa yang berstatus gizi 
overweight, diperoleh 16 siswa $(69,6 \%)$ dengan tekanan darah diastolik yang tergolong normal, 3 siswa $(13,0 \%)$ yang tergolong pre-hipertensi, dan 4 siswa $(17,4 \%)$ yang tergolong hipertensi. Pada 27 siswa berstatus gizi obese, terdapat 18 siswa $(66,7 \%)$ dengan tekanan darah diastolik yang tergolong normal, 4 siswa
$(14,8 \%)$ yang tergolong pre-hipertensi, dan 5 siswa $(18,5 \%)$ yang tergolong hipertensi.

Berdasarkan hasil uji chi-square (Tabel 7), diperoleh nilai $p=0,008(<0,05)$ yang menunjukan bahwa secara statistik terdapat hubungan bermakna antara status gizi dengan tekanan darah diastolik.

Tabel 7. Hubungan status gizi dengan tekanan darah diastolik

\begin{tabular}{lccccc}
\hline Status gizi & \multicolumn{3}{c}{ Tekanan darah diastolik } & Total & p \\
& Normal & Pre-hipertensi & Hipertensi & n (\%) & \\
& $\mathrm{n}(\%)$ & $\mathrm{n}(\%)$ & $\mathrm{n}(\%)$ & & \\
\hline Underweight & $9(100)$ & $0(0)$ & $0(0)$ & $9(100)$ & \\
Normal & $85(91,4)$ & $6(6,5)$ & $2(2,2)$ & $93(100)$ & 0,008 \\
Overweight & $16(69,6)$ & $3(13,0)$ & $4(17,4)$ & $23(100)$ & \\
Obese & $18(66,7)$ & $4(14,8)$ & $5(18,5)$ & $27(100)$ & \\
Total & $128(84,2)$ & $13(8,6)$ & $11(7,2)$ & $152(100)$ & \\
\hline
\end{tabular}

Berdasarkan hasil uji korelasi Spearman terhadap hubungan antara status gizi dan tekanan darah diastolik, diperoleh koefisien korelasi $r=0,319$ dengan nilai $p$ $=0,000$ (Tabel 8). Hasil penelitian ini menunjukkan secara statistik adanya hubungan bermakna antara status gizi dengan tekanan darah diastolik yaitu semakin besar status gizi atau indeks massa tubuh maka tekanan darah diastolik akan makin meningkat.

Tabel 8. Uji korelasi hubungan status gizi dan tekanan darah diastolik

\begin{tabular}{lcc}
\hline & $\begin{array}{c}\text { Koefisien } \\
\text { Korelasi } \\
(\mathbf{r})\end{array}$ & $\begin{array}{c}\text { Kemaknaan } \\
(\mathbf{p})\end{array}$ \\
\hline $\begin{array}{l}\text { Hubungan } \\
\text { status gizi } \\
\text { dengan tekanan } \\
\text { darah diastolik }\end{array}$ & 0,319 & 0,000 \\
\hline
\end{tabular}

Berdasarkan hasil pada Tabel 9, nilai odds ratio (OR) untuk tekanan darah sistolik 6,474 dan diastolik 3,667 yang menunjukkan bahwa siswa yang obese berisiko mengalami peningkatan tekanan darah sistolik sebesar 6,474 kali dibandingkan siswa yang non-obese dan berisiko mengalami peningkatan tekanan darah diastolik sebesar 3,667 kali dibandingkan siswa yang non-obese.

Tabel 9. Estimasi risiko terjadinya peningkatan tekanan darah pada siswa obese

\begin{tabular}{lc}
\hline Peningkatan tekanan darah & OR \\
\hline Tekanan darah sistolik & 6,474 \\
Tekanan darah diastolik & 3,667 \\
\hline
\end{tabular}

\section{BAHASAN}

Penelitian ini dilakukan pada siswasiswi di SD Katolik RK IV Santo Yohanes Manado dari kelas 1 sampai dengan kelas 6. Sampel yang diambil ialah seluruh siswa-siswi SD Katolik RK IV Santo Yohanes Manado yang memenuhi kriteria inklusi. Total sampel yang diperoleh berjumlah 152 siswa. Dari 152 siswa, diperoleh 9 siswa yang berstatus gizi underweight, 93 siswa yang berstatus gizi normal, 23 siswa yang berstatus gizi overweight, dan 27 siswa yang berstatus gizi obese.

Berdasarkan data yang diperoleh, dari 9 siswa yang mengalami underweight, tidak ditemukan adanya peningkatan tekanan darah baik sistolik maupun diastolik. Hasil ini selaras dengan penelitian yang dilakukan pada siswa usia 
8-12 tahun di sebuah sekolah di Thailand, dimana tidak ditemukan siswa underweight yang mengalami peningkatan tekanan darah. ${ }^{9}$ Hasil ini berbeda dengan penelitian yang dilakukan di Kolkata (India), dimana didapatkan 4,3\% anak usia 5-12 tahun yang underweight mengalami hipertensi. Perbedaan hasil ini dapat disebabkan karena jumlah anak yang mengalami underweight di India lebih banyak dibandingkan yang mengalami obesitas. ${ }^{11}$

Dari 23 siswa yang mengalami overweight terdapat $17,3 \%$ siswa yang memiliki tekanan darah sistolik meningkat, sedangkan dari 27 siswa yang mengalami obese didapatkan $40,7 \%$ siswa yang memiliki tekanan darah sistolik meningkat. Pada 23 siswa yang berstatus gizi overweight diperoleh $30,4 \%$ siswa yang memiliki tekanan darah diastolik meningkat, sedangkan pada 27 siswa berstatus gizi obese terdapat $33,3 \%$ siswa yang memiliki tekanan darah diastolik meningkat. Hasil ini lebih tinggi dari penelitian yang dilakukan di Shanghai terhadap anak usia sekolah, dimana hanya terdapat $13,3 \%$ siswa overweight serta $21,6 \%$ siswa obese yang mengalami peningkatan tekanan darah sistolik dan hanya $7,7 \%$ siswa overweight serta $13,4 \%$ siswa obese yang mengalami peningkatan tekanan darah diastolik. ${ }^{12}$

Perbedaan hasil penelitian yang diperoleh dapat disebabkan karena pola makan dan pola aktivitas fisik yang berbeda antara anak usia sekolah di Manado dan di Shanghai. Selain itu, tingkat kesadaran orang tua akan pentingnya pemeriksaan tekanan darah dan status gizi anak sejak dini dapat juga berpengaruh terhadap perbedaan hasil penelitian tersebut.

Dari hasil uji chi-square terhadap status gizi dengan tekanan darah sistolik dan diastolik diperoleh nilai $\mathrm{p}<0,05$. Hasil ini menunjukkan secara statistik bahwa terdapat hubungan bermakna antara status gizi dan tekanan darah baik sistolik maupun diastolik. Hasil ini sejalan dengan penelitian yang dilakukan di Thailand dan Cina Selatan, dimana terdapat hubungan bermakna antara status gizi dengan tekanan darah pada anak usia sekolah. ${ }^{9,13}$

Berdasarkan uji korelasi Spearman, diperoleh nilai koefisien korelasi $r=0.321$ untuk uji korelasi status gizi dengan tekanan darah sistolik dan $r=0.319$ untuk uji korelasi status gizi dengan tekanan darah diastolik. Kedua hasil penelitian ini menunjukkan secara statistik adanya hubungan bermakna antara status gizi dengan tekanan darah (sistolik dan diastolik) yaitu semakin besar status gizi atau indeks massa tubuh maka tekanan darah akan makin meningkat. Hal yang serupa ditemukan oleh penelitian yang dilakukan di Peru, yaitu semakin tinggi indeks massa tubuh, maka prevalensi hipertensi juga semakin tinggi. ${ }^{14}$

Banyak mekanisme yang berperan dalam terjadinya hipertensi pada overweight dan obesitas. Pada obesitas terjadi peningkatan kadar leptin yang memicu aktivasi sistem saraf simpatis serta retensi natrium dan air. ${ }^{7}$ Leptin yang merupakan produk dari ob gene, diproduksi secara teratur oleh jaringan adiposa putih. Leptin kemudian merangsang hipotalamus untuk meningkatkan aktivitas saraf simpatis yang menyebabkan terjadinya retensi natrium dan air. ${ }^{15}$ Hiperinsulinemia dan resistensi insulin yang sering ditemukan pada pasien obesitas merupakan aktivator independen dari sistem saraf simpatis ginjal. Hal ini selanjutnya akan menyebabkan vasokonstriksi dan penurunan aliran darah ginjal yang memicu terjadinya pelepasan renin dan aktivasi RAAS. Selanjutnya akan terjadi retensi natrium dan air yang menyebabkan terjadinya hipertensi. ${ }^{16}$ Terdapat beberapa teori yang mengemukakan mekanisme peningkatan tekanan darah akibat peningkatan kadar asam lemak bebas. Sebagian besar penelitian menjelaskan bahwa terjadi aktivasi saraf simpatis sebagai akibat dari lipolisis. Peningkatan massa lemak dalam tubuh akan menyebabkan lipolisis yang menyebabkan peningkatan pelepasan kadar asam lemak bebas. ${ }^{7,15}$ 


\section{SIMPULAN}

Terdapat hubungan antara status gizi dengan tekanan darah (sistolik dan diastolik) pada anak usia sekolah. Anak dengan overweight dan obese mempunyai risiko lebih tinggi terhadap peningkatan tekanan darah (sistolik dan diastolik).

\section{SARAN}

Perlu dilakukan penyuluhan kepada para guru dan orang tua siswa mengenai pedoman gizi seimbang dan pentingnya memperhatikan status gizi sejak dini.

Perlu dilakukan edukasi terhadap orang tua siswa mengenai pentingnya pemeriksaan tekanan darah secara rutin terhadap anak terutama yang sudah tergolong pre-hipertensi dan hipertensi.

Perlu dilakukan penelitian lebih lanjut mengenai faktor lain yang berhubungan dengan peningkatan tekanan darah pada anak usia sekolah selain status gizi.

\section{DAFTAR PUSTAKA}

1. Almatsier S. Prinsip Dasar Ilmu Gizi. Jakarta: Gramedia Pustaka Utama, 2004; p. 3.

2. Ashworth A. Nutrition, food security, and health. In: Kliegman RM, Stanton BF, St Geme JW, Schor NF, editors. Nelson Textbook of Pediatrics (20th ed). Philadelphia: Elsevier, 2016; p. 297.

3. Osborn D, Cutter A, Ullah F. Universal sustainable development goals: understanding the transformational challenge for developed countries. In Stakeholder Forum, 2015; p. 12.

4. Bovet P, Kizirian N, Madeleine G, Blössner M, Chiolero A. Prevalence of thinness in children and adolescents in the Seychelles: comparison of two international growth references. Nutr J. 2011;10:65.

5. Badan Penelitian dan Pengembangan Kesehatan. Riset Kesehatan Dasar. Jakarta: Kementerian Kesehatan RI, 2013.

6. Victora CG, Adair L, Fall C, Hallal PC, Martorell R, Richter $\mathbf{L}$, et al. Maternal and child undernutrition: consequences for adult health and human capital. Lancet. 2008;371:340 57.
7. Rahmouni K, Correia MLG, Haynes WG, Mark AL. Obesity-associated hypertension: new insights into mechanisms. Hypertension. 2005;45: 11-3.

8. Febba A, Sesso R, Barreto GP, Liboni CS, Franco MP, Casarini DE. Stunting growth: association of the blood pressure levels and ACE activity in early childhood. Pediatr Nephrol. 2009;24:379-86.

9. Sukhonthachit P, Aekplakorn W, Hudthagosol C, Sirikulchayanonta C. The association between obesity and blood pressure in Thai public school children. BMC Public Health. 2014; 14:729.

10. Abdulle A, Al-Junaibi A, Nagelkerke N. High blood pressure and its association with body weight among children and adolescents in the United Arab Emirates. PLoS ONE. 2014;9:1-5.

11. Genovesi S, Antolini L, Gallieni M, Aiello A, Mandal SKB, Doneda A, et al. High prevalence of hypertension in normal and underweight Indian children. J Hypertens. 2011;29:217-21.

12. Lu X, Shi P, Luo C, Zhou Y, Yu H, Guo C, et al. Prevalence of hypertension in overweight and obese children from a large school-based population in Shanghai, China. BMC Public Health. 2013;13:1-7.

13. Zhang CX, Shi JD, Huang HY, Feng LM, Ma J. Nutritional status and its relationship with blood pressure among children and adolescents in South China. Eur J Pediatr. 2012;171:1073-9.

14. Cossio-Bolaños M, Cossio-Bolaños W, Menacho AA, Campos RG, Silva YM, Abella CP, et al. Nutritional status and blood pressure in adolescent students. Arch Argent Pediatr. 2014;112:302-7.

15. Montani JP, Antic V, Yang Z, Dullo A. Pathways from obesity to hypertension: from the perspective of a vicious triangle. Int J of Obesity. 2002;26:2838.

16. Flynn J. The changing face of pediatric hypertension in the era of the childhood obesity epidemic. Pediatr Nephrol. 2013;28:1059-66. 